\title{
Effect of INM Modules and Different Cultural Practices on Properties of Silty Clay Loam Soil
}

\author{
Chandan Singh $^{1 *}$, S.F.A. Zaidi ${ }^{1}$, Manoj Kumar ${ }^{2}$, Rajeev Singh ${ }^{3}$, \\ Vineet Singh $^{4}$ and Maneesh Kumar Singh ${ }^{4}$
}

${ }^{1}$ Department of Soil Science and Agriculture Chemistry, N.D.U.A. \& T. Kumarganj, Faizabad-224229, India

${ }^{2}$ Department of Agronomy, N.D.U.A. \& T. Kumarganj, Faizabad-224229, India

${ }^{3}$ Department of Agriculture Economics, N.D.U.A. \& T. Kumarganj, Faizabad-224229, India

${ }^{4}$ Department of Horticulture, Udai Pratap Autonomous College, Varanasi-221002, India

*Corresponding author

\section{A B S T R A C T}

\section{Keywords}

Rice, INM modules, SRI, Soil nutrient status, Uptake

\section{Article Info}

Accepted: 06 December 2017 Available Online: 10 January 2018
The experiment was conducted during kharif season of 2014-15. In titled effect of different Integrated Nutrient Management modules in different cultural practices on availability of nutrients in silty clay loam soil. SRI cultivation practices with continuous chemical farming; there was not increase in the soil nutrients status and availability nutrient uptake of soil during both the years. However, distinct decrease was noticed in all the values when crops were raised any without on external supplementation of nutrients. The highest profitable treatment was found $\mathrm{T}_{3}-75 \%$ recommended dose of inorganic fertilizer+25\% $\mathrm{Zn}+25 \% \mathrm{GM}-\mathrm{N}$ followed by $100 \% \mathrm{NPK}+\mathrm{Zn}$ (inorganic) and the minimum profitable treatment $75 \% \mathrm{FYM}-\mathrm{N}+25 \% \mathrm{GM}-\mathrm{N}$ (organic).

\section{Introduction}

Rice (Oryza sativa L.) is a staple food for more than 70 per cent of the people living in the Asian continent where more than 90 per cent of rice produced and consumed. It is extensively grown in tropical and sub-tropical regions of the world. In India, rice is second position but first in china. In Indo-gangetic plain rice is almost entirely planted by manual transplanting on puddled bed. Puddling of the soil reduce percolation losses of water, control weed and create favourable condition for rice establishment as well as growth and development besides having better water management. Nevertheless, this has adverse effect on soil physical properties and creates less favourable effect for following crop. SRI was developed in 1980 by Henri de Laulanie, who spent more than three decades in Madagascar trying to devise better production methods that would improve the lives of rural 
household, who were impoverished and heavily dependent on rice (Laulanie, 1993). Farmer's practice is a traditional rice cultivation system, common throughout the rainfed regions of eastern India. This method facilitates stable rice yields under low levels of inputs and uncertain climatic conditions through effective weed control, stimulated root growth and optimum plant stand with enhanced tillering. Sunnhemp and Dhaincha are popular legumes for green manuring in rice and can accumulate up to $100 \mathrm{~kg} \mathrm{~N} \mathrm{ha}^{-1}$ in 50-55 days. Incorporation of these green manures in situ before transplanting rice supplies about 45-60 kg $\mathrm{N} \mathrm{ha}{ }^{-1}$, besides providing a significant residual effect to the succeeding crops.

\section{Materials and Methods}

An experiment was conducted during Kharif season of 2014-15 consecutively on rice in different cultivation practices at instructional farm of Narendra Deva University of Agriculture and Technology, Narendra Nagar (Kumarganj), Faizabad (U.P.). The soil way silt clay loam in texture and saline in reaction ( $\mathrm{pH}$ 8.30), saline having electrical conductivity (EC) of $0.35 \mathrm{dSm}^{-1}$ and bulk density $\left(1.39 \mathrm{Mg} / \mathrm{m}^{3}\right)$. The soil organic content was $(0.33 \%)$ and available $\mathrm{N}, \mathrm{P}, \mathrm{K}, \mathrm{S}$ and $\mathrm{Zn}$ content were $\left(184.00 \mathrm{~kg} \mathrm{ha}^{-1}\right),\left(14.00 \mathrm{~kg} \mathrm{ha}^{-1}\right)$, $\left(220.34 \mathrm{~kg} \mathrm{ha}^{-1}\right),(12.20 \mathrm{ppm})$ and $(0.50 \mathrm{ppm})$ respectively. The main treatment was three like $\mathrm{C}_{1}$ SRI (System of Rice Intensification), $\mathrm{C}_{2}$ Transplanting method and $\mathrm{C}_{3}$ Broad casting but five sub treatment based on recommended dose of fertilizer GM and FYM in different cultivation practices. $\mathrm{T}_{1} 100 \% \mathrm{NPK}+\mathrm{Zn}, \mathrm{T}_{2}$ $75 \% \mathrm{NPK}+\mathrm{Zn} \quad+25 \% \quad \mathrm{FYM}-\mathrm{N}, \quad \mathrm{T}_{3}$ $75 \% \mathrm{NPK}+\mathrm{Zn}+25 \%$ G.M-N， $\mathrm{T}_{4} \quad 50 \% \quad \mathrm{NPK}$ $+\mathrm{Zn}+25 \% \mathrm{FYM}-\mathrm{N}+25 \% \quad \mathrm{GM}-\mathrm{N}, \quad \mathrm{T}_{5} \quad 75 \%$ FYM-N + 25\% GM-N (Table 1). This experiment was laid out in split plot design with three replication. Soil samples were airdried and ground to pass through 2-mm sieve.
Soil $\mathrm{pH}$ in 1:2 soil: water suspension was determined using $\mathrm{pH}$ meter. Available potassium (K) was extracted with $1 N \mathrm{NH}_{4}$ OAc and then measured by flame photometer. Available phosphorus (P) was extracted by Bray-1 (Bray and Kurtz 1945) and then determined by a spectrophotometer. Available $\mathrm{N}$ was determined the method given by Subbiah and Asija (1956) organic carbon (OC) and DTPA extractable micronutrients were determine by Walkley and Black (1934) and Lindsay and Norvell (1978), respectively.

\section{Results and Discussion}

\section{Soil fertility status}

$\mathrm{pH}, \mathrm{EC}, \mathrm{OC}$ and bulk density of the harvest of rice in soil with in a narrow range among different treatments and the differences were statistically non-significant in both the year (Table 2). As the culture practices are concerned generally $\mathrm{pH}, \mathrm{EC}$ and bulk density were found lower down in SRI which similar that conventional practices and broad casting in both year. This may be because of improvement soil quality due to puddling. The soil condition was not affected in broadcasting.

INM module concern was not affected on physical properties of soil e.i. $\mathrm{pH}, \mathrm{EC}, \mathrm{OC}$ and bulk density. The maximum reduction in $\mathrm{pH}$, EC and bulk density was noticed under treatment $\mathrm{T}_{5}-75 \%$ FYM-N $+25 \%$ GM-N followed by $\mathrm{T}_{4}-50 \% \mathrm{NPK}+\mathrm{Zn}+50 \% \mathrm{GM}-\mathrm{N}$ which that similar other INM module treatment in both year. This might be due to production of organic acid from green manure and FYM decomposition resulting lowering of $\mathrm{pH}$ and EC. The application of green manure and FYM manure also increase the formation of humic acid and humus of soil which also responsible for decrease the soil $\mathrm{pH}, \mathrm{EC}$ and bulk density. The reduction of EC of the soil with application of green manure and FYM 
may ascribed to salt leaching facilitated by improve permeability of soil and formation of weak salts which result the reduction in electrical conductivity while decreasing in $\mathrm{pH}$ may be attributed to neutralization of the sodium salt by organic acid and increase the hydrogen ions. Similar findings are observed by Mishra and Sharma (1997), Kumar et al., (2001) and Kaushal et al., (2011).

\section{Availability of N, P, K, S, Zn}

Significantly effect of different cultural practices on availability of nutrients after crop harvest is given in Table 3. Maximum availability of soil nutrient like as $\mathrm{N}, \mathrm{P}, \mathrm{K}, \mathrm{S}$, $\mathrm{Zn}$ were recorded in treatment $\mathrm{C}_{1}$-SRI (194.43, 193.94) followed by $\mathrm{C}_{2}$-transplanting (193.94, 195.03) compare to $\mathrm{C}_{3}$-broadcasting $(189.83,190.91)$ in both year. The improvement in availability of nutrients may be attributed with puddling of rice field but in case of $\mathrm{C}_{1}$-SRI due to more spacing and less transplanting shock plant take up easily nutrient available from the soil but in conventional method the transplanting shock loose the nutrient availability of soil comparison to other cultivation practices. Similar findings are observed by Tiwari et al., (1980), Bajpai et al., (2002), Singh (2005), and Ghosh et al., (2015) and Ghosh et al.,
(2015). The data was significantly affected by INM modules. The maximum buildup of available nitrogen was observed with the application of $\mathrm{T}_{3} 75 \% \mathrm{NPK}+\mathrm{Zn}+25 \% \mathrm{GM}-$ $\mathrm{N}$ (206.52 and 207.61) which at par treatment $\mathrm{T}_{1} 100 \% \mathrm{NPK}+\mathrm{Zn}+25 \%$ GM-N (205.52 and 206.65) compare over rest of the treatment while treatment $T_{4}$ at par as $T_{2}$ and $T_{5}$ in both years. The decline in available nitrogen is sole inorganic fertilizer treatment seemed to be associated with the mobilization of fertilizer, taken by the crop and its leaching from the plough layer $(0-20 \mathrm{~cm})$. Application of green manure and FYM along with inorganic source of nutrient increased available $\mathrm{N}$ in soil.

Among the different sources of organic manure the green manure results higher availability because of its fast decomposition and solubility effect on native soil nutrients which led to better availability of nutrients besides, improving the soil environment. The increase in available nitrogen content with the incorporation of organic source along with inorganic source may be attributed to nitrogen mineralization from organic manure. The most soluble soil condition under organic source might have helped the mineralization of soil $\mathrm{N}$ and buildup of higher available nitrogen. The results also corroborates with by findings of Swarup and Yaduvansi (2013).

Table.1 The treatments and their symbols used in layout

\begin{tabular}{|c|c|c|}
\hline A. & Cultivation practices & Symbol used \\
\hline 1. & SRI (System of Rice Intensification) & $\mathbf{C}_{1}$ \\
\hline 2. & Transplanting method & $\mathbf{C}_{2}$ \\
\hline 3. & Broad casting & $\mathrm{C}_{3}$ \\
\hline B. & $\begin{array}{l}\text { Integrated nutrient management modules (Sub } \\
\text { plot) }\end{array}$ & Symbols used \\
\hline 1. & $100 \% \mathrm{NPK}+\mathrm{Zn}$ & $\mathbf{T}_{1}$ \\
\hline 2. & $75 \% \mathrm{NPK}+\mathrm{Zn}+25 \%$ FYM-N & $\mathbf{T}_{2}$ \\
\hline 3. & $75 \% \mathrm{NPK}+\mathrm{Zn}+25 \% \mathrm{G} . \mathrm{M}-\mathrm{N}$ & $\mathbf{T}_{\mathbf{3}}$ \\
\hline 4. & $50 \% \mathrm{NPK}+\mathrm{Zn}+25 \% \mathrm{FYM}-\mathrm{N}+25 \% \mathrm{GM}-\mathrm{N}$ & $\mathbf{T}_{4}$ \\
\hline 5. & $75 \%$ FYM-N + 25\% GM-N & $\mathbf{T}_{\mathbf{5}}$ \\
\hline
\end{tabular}


Table.2 Effect of INM modules on BD, $\mathrm{pH}, \mathrm{EC}$ and $\mathrm{OC}$ of soil after harvest of basmati rice field under various cultivation practices

\begin{tabular}{|c|c|c|c|c|c|c|c|c|}
\hline \multirow[t]{2}{*}{ Treatments } & \multicolumn{2}{|c|}{ Bulk density } & \multicolumn{2}{|c|}{ pH } & \multicolumn{2}{|c|}{ EC dSm-1 } & \multicolumn{2}{|c|}{$\mathrm{OC}(\%)$} \\
\hline & 2014 & 2015 & 2014 & 2015 & 2014 & 2015 & 2014 & 2015 \\
\hline \multicolumn{9}{|c|}{ A. Cultivation practices } \\
\hline $\mathrm{C}_{1}$ & 1.35 & 1.32 & 8.24 & 8.16 & 0.29 & 0.28 & 0.36 & 0.37 \\
\hline $\mathrm{C}_{2}$ & 1.36 & 1.33 & 8.25 & 8.17 & 0.32 & 0.31 & 0.35 & 0.36 \\
\hline $\mathbf{C}_{3}$ & 1.37 & 1.34 & 8.26 & 8.18 & 0.34 & 0.34 & 0.34 & 0.35 \\
\hline SEm \pm & 0.008 & 0.011 & 0.048 & 0.038 & 0.002 & 0.003 & 0.001 & 0.003 \\
\hline C D $(P=0.05)$ & $\mathrm{N}-\mathrm{S}$ & $\mathrm{N}-\mathrm{S}$ & $\mathrm{N}-\mathrm{S}$ & $\mathrm{N}-\mathrm{S}$ & $\mathrm{N}-\mathrm{S}$ & $\mathrm{N}-\mathrm{S}$ & $\mathrm{N}-\mathrm{S}$ & $\mathrm{N}-\mathrm{S}$ \\
\hline \multicolumn{9}{|c|}{ B. Integrated nutrient management modules } \\
\hline$T_{1}$ & 1.38 & 1.35 & 8.30 & 8.22 & 0.34 & 0.33 & 0.33 & 0.31 \\
\hline$T_{2}$ & 1.37 & 1.34 & 8.27 & 8.19 & 0.31 & 0.30 & 0.34 & 0.35 \\
\hline$T_{3}$ & 1.36 & 1.33 & 8.25 & 8.17 & 0.31 & 0.30 & 0.35 & 0.36 \\
\hline $\mathbf{T}_{4}$ & 1.35 & 1.32 & 8.23 & 8.15 & 0.33 & 0.32 & 0.35 & 0.37 \\
\hline$T_{5}$ & 1.34 & 1.31 & 8.20 & 8.12 & 0.32 & 0.31 & 0.38 & 0.41 \\
\hline SEm \pm & 0.011 & 0.011 & 0.073 & 0.076 & 0.002 & 0.002 & 0.003 & 0.003 \\
\hline$C D(P=0.05)$ & $\mathrm{N}-\mathrm{S}$ & $\mathrm{N}-\mathrm{S}$ & $\mathrm{N}-\mathrm{S}$ & $\mathrm{N}-\mathrm{S}$ & $\mathrm{N}-\mathrm{S}$ & N-S & N-S & $\mathrm{N}-\mathrm{S}$ \\
\hline
\end{tabular}

Table.3 Effect of INM modules on Availability of N, P, K, S and Zn after harvest in soil of basmati rice under various cultivation practices

\begin{tabular}{|c|c|c|c|c|c|c|c|c|c|c|}
\hline \multirow[t]{2}{*}{ Treatments } & \multicolumn{2}{|c|}{ Available $\mathbf{N}$ in soil } & \multicolumn{2}{|c|}{$\begin{array}{c}\text { Available } P \text { in } \\
\text { soil }\end{array}$} & \multicolumn{2}{|c|}{$\begin{array}{c}\text { Available } \mathrm{K} \text { in } \\
\text { soil }\end{array}$} & \multicolumn{2}{|c|}{$\begin{array}{c}\text { Available } S \text { in } \\
\text { soil }\end{array}$} & \multicolumn{2}{|c|}{$\begin{array}{c}\text { Available } \mathbf{Z n} \\
\text { in soil }\end{array}$} \\
\hline & 2014 & 2015 & 2014 & 2015 & 2014 & 2015 & 2014 & 2015 & 2014 & 2015 \\
\hline \multicolumn{11}{|c|}{ A. Cultivation practices } \\
\hline $\mathrm{C}_{1}$ & 194.43 & 195.53 & 15.15 & 15.30 & 234.20 & 234.74 & 18.19 & 18.24 & 0.58 & 0.59 \\
\hline $\mathrm{C}_{2}$ & 193.94 & 195.03 & 15.09 & 15.24 & 231.70 & 232.23 & 17.97 & 18.02 & 0.57 & 0.58 \\
\hline $\mathbf{C}_{3}$ & 189.83 & 190.91 & 15.01 & 15.16 & 229.11 & 229.63 & 17.68 & 17.73 & 0.55 & 0.56 \\
\hline SEm \pm & 1.049 & 1.056 & 0.070 & 0.069 & 1.405 & 1.408 & 0.105 & 0.106 & 0.003 & 0.004 \\
\hline $\mathrm{CD}(\mathrm{P}=0.05)$ & 4.119 & 4.146 & 0.274 & 0.270 & 5.518 & 5.530 & 0.411 & 0.412 & 0.013 & 0.014 \\
\hline \multicolumn{11}{|c|}{ B. Integrated nutrient management modules } \\
\hline $\mathrm{T}_{1}$ & 205.52 & 206.65 & 15.15 & 15.30 & 238.02 & 238.56 & 19.00 & 19.05 & 0.58 & 0.59 \\
\hline $\mathbf{T}_{2}$ & 183.44 & 184.52 & 14.77 & 14.92 & 228.39 & 228.91 & 17.00 & 17.05 & 0.56 & 0.57 \\
\hline$T_{3}$ & 206.52 & 207.61 & 15.43 & 15.58 & 240.84 & 241.39 & 20.00 & 20.05 & 0.60 & 0.61 \\
\hline$T_{4}$ & 185.24 & 186.33 & 15.13 & 15.28 & 226.46 & 226.98 & 18.00 & 18.05 & 0.56 & 0.58 \\
\hline $\mathrm{T}_{5}$ & 182.24 & 184.00 & 14.93 & 15.08 & 224.65 & 225.16 & 15.76 & 15.80 & 0.54 & 0.56 \\
\hline $\mathrm{SEm} \pm$ & 1.203 & 1.211 & 0.113 & 0.115 & 1.599 & 1.603 & 0.125 & 0.126 & 0.004 & 0.004 \\
\hline $\mathrm{CD}(\mathrm{P}=0.05)$ & 3.476 & 3.498 & 0.327 & 0.348 & 4.618 & 4.629 & 0.362 & 0.363 & 0.013 & 0.011 \\
\hline
\end{tabular}

The available phosphorus in soil significantly increased with the application of $\mathrm{T}_{3} 75 \%$ NPK $+\mathrm{Zn}+25 \%$ GM-N (15.43 and 15.58) followed by $\mathrm{T}_{1} 100 \% \mathrm{NPK}+\mathrm{Zn}+25 \%$ GM-N (15.15 and 15.30) as compare to treatment $\mathrm{T}_{4}$, $T_{2}$ and $T_{1}$ while treatment $T_{1}$ was significantly lower to over treatment respectively in both year. This might be due to favorable soil condition by the application of organic manure which increased activity of microbes and thereby increase in available phosphorus status of soil. Similar findings were observed 
by Tadesse et al., (2013). It is clear from the data that the available $\mathrm{K}, \mathrm{S}$ and $\mathrm{Zn}$ status in soil after harvest of rice crop varied due to the application of various combination of organic and inorganic source of nutrient. These results clearly indicated that the appreciable increase in available $\mathrm{K}, \mathrm{S}$ and $\mathrm{Zn}$ was noted over control.

The maximum build up available $\mathrm{K}, \mathrm{S}$ and $\mathrm{Zn}$ were founded under the treatment having $\mathrm{T}_{3-}$ $75 \% \mathrm{NPK}+\mathrm{Zn}+25 \% \mathrm{GM}-\mathrm{N}$ (240.84 and 241.39), (20.00 and 20.05) and (0.60 and $0.61)$ on par $\mathrm{T}_{1}-100 \% \mathrm{NPK}+\mathrm{Zn}$ to under over other treatments but treatment $\mathrm{T}_{4}$ similar that $T_{2}$ and $T_{1}$ in both years respectively. The application of organic manure might also be attributed to the direct addition of potassium in the available $K$ pool of the soil which ultimately improved the availability of potash at harvest. Similar findings were also observed by Singh et al., (2005) and Singh and Singh (2007).

Improvement in status of available sulphur in soil after harvest of crop might be due to addition of nutrients through inorganic ( $\mathrm{Zn}$ $\mathrm{SO}_{4}$ ) along with organics (FYM and GM). Besides production of carbon dioxide and organic acid during the decomposition increased the availability of nutrients from mineralizable native as well as applied fertilizers. Similar finding were observed by Singh et al., (2005). The green manure and FYM along with combination of inorganic fertilizers, increased in availability of zinc in soil may be a scribed due to additive supply of zinc through FYM, green manure and $\mathrm{ZnSO}_{4}$ fertilizer. Similar findings were observed by Kumar and Yadav (1995) and Singh and Singh (2007).

It is concluded that the maximum availability of nutrient treatment with $\mathrm{C}_{1}$-SRI method followed by transplanting and beside treatment $\mathrm{T}_{3}-75 \% \mathrm{NPK}+\mathrm{Zn}+25 \% \mathrm{GM}-\mathrm{N}$ with higher availability of $\mathrm{N}, \mathrm{P}, \mathrm{K}, \mathrm{S}$, and $\mathrm{Zn}$ followed by $\mathrm{T}_{1}-100 \% \mathrm{NPK}+\mathrm{Zn}$ as compare to over rest of the treatment.

\section{References}

Bajpai, R.K., Upadhyay, S.K., Joshi and Thripathi, R.S. 2002. Productivity and economics of rice (Oryza sativa L.) wheat (Triticum aestivum L.) cropping under integrated nutrient supply system. Indian J. Agronomy, 47 (1): 20-25.

Ghosh, D.C., Ghosh, M. Garnayak L. M. and Panigrahi Trinath 2015. Growth analysis of basmati rice varieties and its impact on grain yield under SRI. International Journal of Plant, Animal and Environmental Sciences; May 2015, Vol. 5 Issue-3, pp. 101-109.

Ghosh, D.C., Ghosh, M. Garnayak L. M. Panigrahi Trinath and Bastia D.K. 2014. Productivity and profitability of basmati rice varieties under SRI. International Journal of Bio-Resource and Stress Management; 2014, 5(3) pp. 333-339.

Koushal, S., Sharma, A. K and Singh, A. 2011. Yield performance, economics and soil fertility through direct and residual effects of organic and inorganic sources of nitrogen as substitute to chemical fertilizer in rice-wheat cropping system. Research Journal of Agricultural Science, 43(3): 189-193.

Kumar, A. and Yadav, D.S. 1995. Use of organic manures and fertilizer in ricewheat cropping system and for sustainability. Indian J. Agric. Sci. 65 (10): 703-707.

Kumar, N., Verma, L.P., Singh, R. and Prasad, K. 2001. Soil properties, nutrients uptake and productivity of rice under integrated nutrient management system. Annals plant and Soil Res., 3(1): 54- 57.

Laulanie, H, 1993. The system de riziculture intensive malagache, Tropicultura 
(Brussels), 11, 110-114, 1993.

Mishra, V. K. and Sharma, R. B. 1997. Influence of integrated nutrient management on soil health and energy requirement of rice - wheat cropping system. Oryza, 34: 165-170.

Singh, P.K. 2005. Comparative performance of green manuring of Dhaincha (Sesbania aculeate L.) and Sunhemp (Crotolaria juncea) on productivity and nitrogen uptake in rice (Oryza sativa L.) crop. M.Sc. (Ag.) Soil Science Thesis, NDUA\&T, Kumarganj, Faizabad (UP).

Singh, V. and Singh, S.P. 2007. Productivity and economics of rice berseem cropping sequence under integrated nutrient supply system in reclaimed sodic soil. Annals of plant and Soil Science; 9 (2): 109-112.

Swarup, A. and Yaduvanshi, N.P.S. 2013.
Response of rice and wheat to organic and inorganic fertilizer and soil amendment under sodic water-irrigated condition. International Rice Research Notes, 29(1): 49-51.

Tadesse, T., Dechassa, N., Bayu, W. and Gebeyehu, S. 2013. Effects of Farmyard Manure and Inorganic Fertilizer Application on Soil Physico-Chemical Properties and Nutrient Balance in Rain-Fed Lowland Rice Ecosystem, FYM, Nitrogen, Phosphorous, Nutrient Balance, Rain-Fed Rice. American Journal of Plant Sciences; 4 (3) 309316.

Tiwari, K.N., Tiwari, S.P. and Pathak, A.N. 1980. Studies on green manuring of rice in double cropping system in a partially reclaimed saline sodic soil. Indian $J$. Agronomy, 25: 136-145.

\section{How to cite this article:}

Chandan Singh, S.F.A. Zaidi, Manoj Kumar, Rajeev Singh, Vineet Singh and Maneesh Kumar Singh. 2018. Effect of INM Modules and Different Cultural Practices on Properties of Silty Clay Loam Soil. Int.J.Curr.Microbiol.App.Sci. 7(01): 653-658. doi: https://doi.org/10.20546/ijcmas.2018.701.079 